\title{
KÖNYVJELZÖ
}

\section{LUKOVICH TAMÁS: A POSZTMODERN KOR VÁROSÉPÍTÉSZETÉNEK KIHÍVÁSAI}

\author{
(Budapest, Szószabó Stúdió 1997)
}

\section{BÖDY PÁL}

Lukovich Tamás a Budapesti Mủszaki Egyetemen szerezte építö- és építészmérnöki diplomáit, késóbb közel tỉz évig foglalkozott várostervezéssel a VẢTI néven ismert legnagyobb magyar tervező intézetben. Könyvének mondanivalója hat éves külföldi tanulmányút keretében kifejtett oktatói, kutatási tevékenység eredményének tekinthető. Tanulmányai során a szerző az ausztráliai University of New South Wales egyetemen a várostervezés tanára volt, valamint tanulmányokat folytatott az USA, Anglia, Hong Kong és Izrael neves egyetemein.

A szerző törekvése arra irányul, hogy bemutassa a nyugati (elsősorban angol-amerikai) városépítészet gondolkodását, irányzatait, eredményeit azzal a céllal, hogy ösztönözze a magyar urbanisztikát.

A könyv elsö szakaszában mindjárt szembesülünk egy fogalmi kérdéssel. A városépitészetnek az angol nyelvterületen több fogalmi változata lehetséges, ezeknek a fogalmaknak a tartalma eltérö. A városépítészetet a szerző forditása alapján az „urban desing” kifejezéssel jelölhetjük, ez a város fizikai infrastruktúrájának tervezését jelenti. Vannak olyan fogalmak, mint az ,urban planning”, „urban development”, „urban policy”, melyek nemcsak az épített környezetre vonatkoznak, hanem átfogó fejlesztési folyamatot jelentenek, melyek társadalmi, gazdasági, népességi, közösségfejlesztő városi igényeket hivatottak kielégíteni. A szerző nyilvánvalóan erre a második fogalomra is gondol, amikor könyvének mondanivalóját kifejti, azonban általában az első fogalmat alkalmazza. Mivel a könyv valószínủleg termékeny vitához fog vezetni, érdemes a fogalmak pontos tisztázása.

A könyv fejezetei egyrészt ismertetik a városépítészet elméleti irányzatait, így pl. a neoracionalizmus és neoempirizmus szempontjait, valamint Abraham Maslow motiváció elméletét, másrészt pedig gyakorlati, városépitészeti, a városkörnyezetet alakító javaslatokat mutatnak be, melyek kitünő vitaindító szerepet játszhatnak a jelenkori magyar urbanisztika elveinek, gyakorlatának tisztázásában.

A könyv mondanivalója három témakör szerint csoportosítható. Az elsö, kapcsolódva a városépítészeti eiméletekhez, abban jelölhető meg, hogy a szerző a neoempirizmusnak nevezett városépítészeti irányzatot tartja meghatározónak, ez az a program, amelyet ö is elfogad és követendönek tart. Ezt az irányzatot olyan neves 
urbanista írók képviselik, mint Gordon Cullen, Kevin Lunch, Robert Venturi, Christopher Alexander.

Bár ezek az elméletek elsősorban az „urban desing”, tehát a hagyományos városépítészet fogalmához kapcsolódnak, egyes írók, mint pl. Kevin Lunch, nagy hatást gyakoroltak a városfejlesztés jelenkori gyakorlatára és elméletére. Ez a városszemlélet döntően hangsúlyozza a város vizuális jellegét, amely nem csak az épitett környezetre, hanem az emberi tevékenységre is vonatkozik. Lunch írásaiban a város építészeti és lakossági kapcsolatrendszerét vizsgálta, és a városi térség, a városi környezet tudatos formálását hangsúlyozta. Érdekes momentum, hogy Kepes György, magyar származású urbanista, jelentősen befolyásolta elképzeléseit. Donald Appleyard hasonlóképpen az utcai hálózat, az életminőség és a társadalmi funkciók szerves kapcsolatát mutatta be. Gondolatvilága szintén jelentősen formálta az amerikai városfejlesztés új irányzatait.

Lunch és Appleyard nézöpontja a második világháború utáni modernizmus, vagyis a rosszul átgondolt várospolitika ismeretében értékelhető. Mindketten ahhoz a csoporthoz tartoztak, akik szakmai tudással, társadalmi elkötelezettséggel fejtették ki a város emberi környezetének jelentőségét. Ezért hangsúlyozzák a városi térséget, a térség környezetét, történetét, emberi dimenzióját. Ezzel kapcsolatban idézzük a szerző interpretációját: „,...világos, hogy a modernizmus szellemében épült új városok és lakótelepek többségének nem sikerült igazi helyeket létrehozniuk, amelyek a társadalmi, kulturális és fizikai igényekre megfelelően reagálnának. A hatvanashetvenes évek városfejlesztését a beruházások gazdaságossága és a technikai kísérletezések egyeduralma jellemezte."

A második jelentős témakör a tervezés folyamatával, módszereivel, valamint azzal az alapvető kérdéssel foglalkozik, hogyan építhetők be a városépítészeti folyamatba a városi lakosság érdekei, igényei, kívánságai. Ez a kérdés szükségszerủen nem csak a szigonúan értelmezett városépítészetet érinti, hanem a városfejlesztés átfogó, emberi igényeket tiszteletben tartó irányzatát is. A szerző részletesen ismerteti azokat a módszereket, amelyeket az amerikai, angol, német városfejlesztés az elmúlt évtizedekben alkalmazott. Ennek a városfejlesztést kiegészítő feladatnak a nemzetközileg elismert neve: közösségi részvétel - közösségi tervezés. Megemlitjük, hogy a szerzö felsorolja a pro- és kontra érveket, valamint a közösség bevonásának akadályait, elönyeit és hátrányait.

Álláspontja abban fogalmazható meg, hogy szükségszerủnek tartja három, a tervezésben résztvevő csoport szempontjainak érvényesitését: a lakosságét, a tervezökét és a közhivatalnokokét. Véleménye szerint a lakosság feladata és joga, hogy körvonalazza a célokat, és az alternatív megoldások között válasszon. Aktív részvételüket azért is fontosnak tartja, mert véleménynyilvánításuk jelzést ad a tervezöknek arra nézve, hogy a szakmai döntések összhangban vannak-e vagy sem a közösség igényeivel. A közhivatalnok felelőssége pedig abban áll, hogy az általános célokat érvényesítse, a végleges döntéseket meghozza, a terveket elfogadtassa, és a megvalósításhoz szükséges forrásokat biztosítsa. 
Ez az alapvetően pluralista, a résztvevő szerepek meghatározását igénylő álláspont mindenképpen megfontolásra méltó a magyar urbanisztikai elmélet és gyakorlat felújitásában.

A szerzö több olyan eszközt sorol fel, mely a folyamatot érvényre juttatja, és közel hozza a lakossághoz: kiállitások, lakossági gyúlések, fórumok, információdokumentálás, kérdöivek, sajtó, ötletpályázat, népszavazás, nyilvános vizsgálatok, a Delphi-módszer, a névleges csoportmódszer, SWOT-elemzés, erőtérelemzés, brainstorming, charette, stratégiai választás, forgatókönyvirás, játszma-szimuláció, internet.

Elgondolkodtató a szerzö következő megállapitása: „Közösségi érzés, büszkeség, kötödés a lakókörnyezet múltjához és jelenéhez csak akkor jöhet létre, ha a polgároknak valamilyen jellegü beleszólásuk van környezetük alakításába. A kérdés nem az, hogy kell-e vagy legyen-e közösségi részvétel a tervezésben. Az emberek egy része részt kíván abban venni. A kérdés az, hogy kik, mikor és hogyan. A törvények és a gyakorlat lehetővé kell, hogy tegyék ezt, a szakembereknek pedig minden segítséget meg kell adniuk ehhez."

A könyv harmadik jelentős témaköre a szerző saját megfogalmazásában az emberi tényezỏ fogalmával jellemezhetö. Kiindulópontját abban a célkitüzésben határozza meg, miszerint a kortárs városépítészet célja az lehet, „... hogy olyan városi (közösségi) területeket, illetve létesítményeket hozzon létre, amelyek lehetỏvé teszik az emberi igények mind teljesebb kielégítését." Érdekes és jelentős az a kiegészítése, melyben Christopher Alexander megjegyzését idézi: „Szerinte a jó környezet nem annyira a szükségleteket elégíti ki, hanem lehetövé teszi az embereknek, hogy maguk elégítsék ki igényeiket. A környezet egyetlen feladata, hogy biztosítsa ezt a lehetöséget."

$\mathrm{Az}$ idézett megállapítás tartalmazza a szerző városépítészeti programját. Ez a program nem annyira a múszaki létesítmények építésével foglalkozik, hanem egy emberi törekvéseket lehetővé tevő környezet tervezésével, kialakításával. Egy ilyen környezet megalkotása pedig elsősorban társadalmi, közösségi feladat.

E feladat megvalósítását két egymáshoz kapcsolódó szakaszban fejti ki. Az elsőben Abraham Maslow motiváció elméletét alkalmazza az emberi igények városkörnyezeti meghatározására, a másodikban pedig ezeknek az igényeknek a megvalósítását javasolja a kortárs városépítészet feladatainak megállapításával.

Az első kérdéssel kapcsolatban Maslow elmélete hat különböző emberi igényt fogalmaz meg: fiziológiai igények, biztonsággal kapcsolatos igények, hovatartozás igénye, megbecsủléssel összefüggö igények, önmegvalósítás igénye és kognitívesztétikai igények. A szerző elemzése, városépítészeti vizsgálata mindenképpen helytálló. A különbözö igények kielégítése szempontjából kifejti azokat a városfejlesztési feladatokat, melyek a kortárs város kialakításában ajánlatosak és az emberi környezet szempontjából meghatározóak. A felsorolt feladatok alapján és a megfelelő szakirodalom eredményeivel összhangban megállapítja a várostervezés jelentős célkitủzéseit. Ezek: az átjárhatóság, a vitalitás, az áttekinthetőség, illetve az olvashatóság, a funkcionális rugalmasság, az érzékszervi gazdagság, a személyesség, 
illetve az otthonosság és a fenntarthatóság. A felsorolt célkitüzések alkalmazását szakmai alapossággal, valamint az emberi tényezö iránt megnyilvánuló elkötelezettséggel vizsgálja és javasolja.

Lukovich Tamás kitünő tanulmányában kettós feladatot teljesitett: egyrészt ismertette a nyugati társadalomban lezajlott paradigmaváltást, mely az 1945-1970 kőzötti aranykorszakban fejeződött be az urbanisztikában, valamint a társadalmi szemléletben egyaránt, másrészt pedig kifejtette az új urbanisztika alapelveit és alkalmazási lehetőségeit a magyar városfejlesztés következő szakaszában. 